\title{
Alcohol consumption and associated factors with alcohol consumption among university students
}

\section{Üniversite öğrencilerinde alkol kullanımı ve alkol kullanımı ile ilişkili faktörler}

\author{
Ebru ALDEMİR ${ }^{1}$, Hande ÇELIKAY ${ }^{1}$, Demet HAVAÇELİ̆́̆ ATLAM $^{1}$, Kültegin ÖGEL $^{2}$, \\ Ayşe Ender ALTINTOPRAK ${ }^{3}$
}

${ }^{I}$ Ege Üniversitesi Madde Bă̆ımlılı̆̆ı, Toksikoloji ve İlaç Bilimleri Enstitüsü, İzmir, Türkiye ${ }^{2}$ Moodist Psikiyatri ve Nöroloji Hastanesi, İstanbul, Türkiye

${ }^{3}$ Ege Üniversitesi Tıp Fakültesi, Psikiyatri Anabilim Dall, İzmir, Türkiye

\begin{abstract}
Objective: University period is associated with many fundamental changes in human life. During this period the incidence of alcohol use, and related problems increases . The present study aimed to determine the prevalence of alcohol use, risky drinking and heavy drinking among university students and to investigate psychological, behavioral and social factors associated with alcohol use.

Method: This cross sectional, web-based, self-report study was carried out in Ege University between 2012 September-2013 September. The assessment form included sections of demographic data, alcohol use and characteristics associated with alcohol use. Risky drinking was measured by CAGE questionnaire. The analysis was conducted with 2973 subjects.

Results: Majority $(76.2 \%)$ of participants had at least used alcohol once in their lifetime, while $12.1 \%$ had a history of risky and $37.2 \%$ had heavy drinking. History of substance use and smoking were the factors affecting lifetime use of alcohol and risky drinking and heavy drinking. Problematic alcohol use of siblings was the factor affecting lifetime use of alcohol and risky drinking. While living alone or with friends was the factor affecting lifetime use of alcohol and heavy drinking. Physical fights and injuries, self-harming behavior, being exposed to violence from a partner and, planning/attempting suicide were seen at higher rates in students with lifetime use of alcohol, risky and heavy drinking.

Conclusion: The prevalence of alcohol use and factors associated with alcohol use in university students indicate that community and university supported preventive interventions are required in this population.
\end{abstract}

Keywords: Alcohol use, university student, Turkey

\section{$\ddot{\mathbf{O Z Z}}$}

Amaç: Üniversite dönemi, bireylerin yaşamında belirgin değişikliklerin olduğu bir dönemdir. Bu dönemde, öğrencilerin alkol kullanımı ve alkol kullanımıyla ilgili sorunlar artmaktadır. Çalışmamızın amacı, üniversite öğrencilerinde yaşam boyu alkol kullanımı, alkol bağımlılığı riski ve ağır içicilik yaygınlığını saptamak ve alkol kullanımıyla ilişkili ruhsal, davranışsal ve sosyal faktörleri araştırmaktır.

Yöntem: Kesitsel desendeki, web tabanlı, özbildirime dayalı bu çalışma, 2012 Eylül-2013 Eylül eğitim-öğretim döneminde Ege Üniversitesinde gerçekleştirildi. Değerlendirme formu; demografik verileri, alkol kullanımı ve alkol kullanımıyla ilişkili özellikleri değerlendiren bölümleri içermekteydi. Alkol bağımlılı riski, formda yer alan CAGE testi ile değerlendirildi. Analiz $2.973 \mathrm{olgu}$ temel alınarak yürüttüldü.

Bulgular: Örneklemin yaşam boyu en az bir kez alkol kullanım oranı \%76,2 idi. \%12,1'inde alkol bağımlılı̆̆ı riski, \%37,2'sinde ağır içicilik mevcuttu. Madde ve sigara kullanımı öyküsü, yaşamboyu alkol kullanımı, bağımlılık riski ağır içiciliği etkileyen faktörlerdi; kardeşlerde sorunlu alkol kullanımı yaşam boyu alkol kullanımı ve bağımlılık riskini etkileyen faktör, yalnız veya arkadaşlarla yaşıyor olmak da yaşam boyu alkol kullanımı ve ağır içiciliği etkileyen faktörlerdi. Yaşam boyu alkol kullanımı, bağımlılık riski ve ağır içici olan öğrencilerde fiziksel kavgada bulunma veya yaralanma, kendine zarar verme davranışı, kız veya erkek arkadaşından şiddet görme ve intiharı planlama veya deneme girişimleri daha fazlaydı.

Sonuȩ: Üniversite öğrencilerindeki mevcut alkol kullanım yaygınlığı ve alkol kullanımıyla ilişkili faktörler, bu gruba yapılacak toplum ve üniversite destekli önleme girişimlerinin gerekliliğini göstermektedir.

Anahtar kelimeler: Alkol kullanımı, Türkiye, üniversite öğrencisi

Alındığı tarih: 16.07.2017

Kabul tarihi: 26.12.2017

Yazışma adresi: Uzm. Dr. Ebru Aldemir, Ege Üniversitesi Madde Bağımlılığı, Toksikoloji ve İlaç Bilimleri Enstitüsü, Ankara Asfaltı, Bornova 35100 İzmir / Türkiye

e-mail: ozturk.ebru2000@gmail.com 


\section{INTRODUCTION}

University period is associated with many fundamental changes in human life such as being separated from home, being far from the supervision of parents, and increase in social interaction with peers during campus life ${ }^{(1)}$. These changes are accompanied by increases in alcohol consumption and heavy and risky drinking ${ }^{(2)}$. Epidemiological studies demonstrate that alcohol consumption and heavy drinking are both more common among university students than their peers who are not attending university ${ }^{(3)}$. It has been reported that in spite of serious attempts to decrease underage alcohol use, which has become more common during the last two decades, over $90 \%$ of university students use alcohol and that $40-45 \%$ of them have a history of heavy drinking during university period ${ }^{(4)}$.

Alcohol use leads to many risky behaviors among university students. Driving under the influence of alcohol, unsafe sexual activity, use of illicit drugs, antisocial behaviors, engaging in fights, interpersonal violence, low academic performance and development of alcohol dependence are a few of these risky behaviors ${ }^{(5-7)}$. Moreover, in the young age groups between $15-19,9 \%$ of deaths have been reported to be associated with alcohol ${ }^{(8)}$.

In the face of these negative consequences, the volume of consumption (mostly expressed as the number of standard drinks per day) (one standard drink contains roughly 10-12 grams of pure alcohol) and the patterns of alcohol consumption play a part as well. For example, recurrent heavy drinking which is defined as consumption of 60 or more grams of pure alcohol (6+ standard drinks in most countries) on at least one single occasion ${ }^{(9)}$ is a drinking pattern that appears to exacerbate alcohol-related harm in the population. It has been reported that this pattern of alcohol consumption is a source of problems not only in the U.S. and but also in other countries ${ }^{(10)}$. In addition, studies show that as the duration of heavy drinking is prolonged, the probability of experiencing social, physical and legal problems increases as well ${ }^{(4)}$.
Most of the studies conducted in the last decade concerning alcohol consumption and alcohol-related harm among university students came from the U.S. and Western European countries ${ }^{(2,5,7,11)}$. Turkey has a very diverse culture that is a blend of various elements of the Islamic and Western culture. Alcohol consumption is legal in Turkey but it is prohibited in the religion of Islam. Therefore, the data on alcohol consumption and alcohol-related harm among university students from Turkey will be an important addition to literature.

There are a few studies in Turkey with small sample sizes regarding the prevalence of alcohol consumption among university students ${ }^{(12-14)}$. The prevalence of alcohol consumption and associated alcoholrelated harm should be studied with larger samples so as to develop prevention programs for university students.

The purpose of the present study is to determine the prevalence of alcohol use, risky and heavy drinking among university students in Turkey and to investigate psychological, behavioral and social factors associated with alcohol use.

\section{MATERIAL and METHODS}

\section{Study design}

This web-based cross-sectional study was carried out in Ege University between 2012 September-2013 September. The questionnaire was placed on university data base and it was completed online via web.

\section{Setting and sample}

In the calculation of sample size, the prevalence of the substance, the use of which was found at the lowest rate (heroin) $(0.02 \%)$ in similar studies ${ }^{(1)}$ was taken into consideration. In statistical power analysis for the population of the university with $53,003 \mathrm{stu}-$ dents, at $95 \%$ confidence interval and \pm 0.03 standard deviation, a sample size consisting of 3184 subjects were found to be adequate.

During the online pre-enrollment process, 4307 subjects filled the questionnaires. A drug named 
"relaktin" was added as a dummy drug to the survey. Three hundred and twenty-five subjects who said "yes" to the question about the use of "relaktin" were excluded from the study. Findings of 2973 subjects who completed all questions of the survey forms were evaluated.

\section{Ethical consideration}

Ethical approval was obtained from ethical council of the university prior to the study (approval no. 2037). Participation was voluntary and questionnaire was anonymous. Informed consent was obtained by clicking the related link in the web site.

\section{Measurements}

\section{Lifetime Use of Alcohol}

Alcohol consumption was evaluated with the question "How often do you use alcohol?" Answer options were as follows: "I never used alcohol", "I used alcohol only once", "I use alcohol 1-3 times a month", "I use alcohol 1-5 times a week", "I use alcohol almost every day". For analysis two groups of students were defined: Those who did not report any alcohol use (the answer "never") and those who reported intake of alcoholic beverage at least once in their lifetime (all other answers).

\section{Risky drinking}

Risky drinking was evaluated using 4-item CAGE test ${ }^{(15)}$. The CAGE test has been developed to diagnose lifetime alcohol dependence and consists of 4 dichotomous (the answers are "yes" or "no") questions: "Have you ever felt you should CUT down on your drinking?", "Have people ANNOYED you by criticizing your drinking?", "Have you ever felt bad or GUILTY about your drinking?" and "Have you ever had a drink as the first thing in the morning (as an 'EYE opener') to steady your nerves or get rid of a hangover?" Risky drinking is defined as a CAGE score of 2 or more ${ }^{(16)}$ which means that there is a risk for alcohol dependence.

\section{Heavy drinking}

Heavy drinking was evaluated with the following question: "What is your frequency of drinking 6 or more standard drinks on one occasion (for example 6 glasses of wine or 4 big bottles of beer)?" The answer options were "never", "less than once a month", "once a month", "once a week" and "almost every day". For the analysis, two groups of students were defined: those who did not report heavy drinking (the answer "never") and those who reported heavy drinking (all other answers).

\section{Sociodemographic and other variables}

The questionnaire included sections of demographic data, use of illicit drugs, problematic alcohol use in parents and siblings, use of cigarettes, and energy drinks, engaging in physical fights or getting injured in physical fights, carrying knives/penknives/ arms, self-harming behaviors, being exposed to violence from a partner, suicidal plans and attempts, unsafe sexual activity and self-evaluation of psychological and physical health status as bad, moderate and good. Additionally, depression and anxiety subscales of Addiction Profile Index (BAPI) were used (17). Depression was evaluated with 4 ("I thought about putting an end to life in the past year", "I felt sad in the past year", "When I thought about the future, I felt a sense of despair in the past year", "When I compared myself with other people in the past year, I saw myself worthless"), anxiety was evaluated with 3 ("I felt anxious and restless over the past year", "I experienced horror or panic attacks over the past year", "I felt so restless that I could not stop by myself in the past year") questions. The answers were arranged along a 3-point Likert-type scale: 1) Never 2) Sometimes 3) Almost every time. BAPI depression subscale was correlated with the Beck Depression Inventory ( $\mathrm{r}^{1 / 40.65)}$ and depression subscale of the Symptom Checklist-90-R (SCL90-R) ( $\mathrm{r}^{1} \frac{1}{40.63)}$ and BAPI anxiety subscale was correlated with the State-Trait Anxiety Inventory (STAI) State Anxiety $\left(\mathrm{r}^{1 / 40.52)}\right.$ and anxiety subscale of SCL$90\left(\mathrm{r}^{1 / 40.54)}\right.$. 


\section{Data collection and procedure}

Before data collection, 12 faculties, 7 institutes and 12 colleges were officially informed about the research and got permission. The survey was advertised by posters and online in the university. The faculties, institutes and colleges hung the posters and put the link on their official web and facebook. During a year, the students fulfilled the questionnaire. The researchers followed the results on online system.

\section{Data analysis}

Analysis was performed with SPSS for Windows (version 22.0). In order to evaluate categorical data and to determine the difference between groups, Pearson chi-square test was used. In order to determine the probability of independent variables affecting alcohol use, logistic regression analysis was performed with enter method. In the present study, $\mathrm{p}$ value of $<0.05$ was considered statistically significant.

Table 1. Sociodemographic characteristics.

\begin{tabular}{|c|c|c|c|}
\hline & $\begin{array}{l}\text { Females } \\
(n=1629)\end{array}$ & $\begin{array}{c}\text { Males } \\
(n=1344)\end{array}$ & $\begin{array}{c}\text { Total } \\
(\mathrm{n}=\mathbf{2 9 7 3})\end{array}$ \\
\hline Age (years, mean \pm SD) & $22.54 \pm 2.91$ & $23.23 \pm 3.01$ & $22.85 \pm 2.97$ \\
\hline \multicolumn{4}{|l|}{ Class level n (\%) } \\
\hline Undergraduate & $1462(89.7)$ & $1249(92.9)$ & $2711(91.2)$ \\
\hline Postgraduate & $167(10.3)$ & $95(7.1)$ & $262(8.8)$ \\
\hline \multicolumn{4}{|l|}{ Academic programs n (\%) } \\
\hline College & $252(15.5)$ & $162(12.1)$ & $414(13.9)$ \\
\hline Faculty & $1254(77)$ & $1120(83.3)$ & $2374(79.7)$ \\
\hline Institute & $123(7.6)$ & $62(4.6)$ & $185(6.2)$ \\
\hline \multicolumn{4}{|l|}{ Economic status n (\%) } \\
\hline Good & $501(30.8)$ & $323(24)$ & $824(27.7)$ \\
\hline Average & $968(59.4)$ & $838(62.4)$ & $1806(60.7)$ \\
\hline $\mathrm{Bad}$ & $160(9.8)$ & $183(13.6)$ & $343(11.5)$ \\
\hline \multicolumn{4}{|l|}{ Household conditions n (\%) } \\
\hline Family/dormitory & $1129(69.3)$ & $688(51.2)$ & $1817(61.1)$ \\
\hline Alone/with friends & $438(26.9)$ & $589(43.8)$ & $1027(34.5)$ \\
\hline Other & $62(3.8)$ & $67(5)$ & $129(4.3)$ \\
\hline \multicolumn{4}{|l|}{ Marital Status of Parents n (\%) } \\
\hline Married parents & $1357(83.3)$ & 1139 (84.7) & $2496(84)$ \\
\hline Divorced/separated parents & $168(10.3)$ & $127(9.4)$ & $295(9.9)$ \\
\hline Loss of a parent & $104(6.4)$ & $78(5.8)$ & $182(6.1)$ \\
\hline \multicolumn{4}{|l|}{ Loss of an academic year $n(\%)$} \\
\hline Yes & $1481(90.9)$ & $1086(80.8)$ & $2567(86.3)$ \\
\hline No & $148(9.1)$ & $258(19.2)$ & 406 (13.7) \\
\hline
\end{tabular}

\section{RESULTS}

\section{Description of the sample}

Sociodemographic characteristics of the sample were demonstrated in Table 1 . Of the students participating in the study, 1629 were female $(54.8 \%)$ and 1344 were male $(45.2 \%)$ and the mean age of the study participants was $22.9 \pm 3$ years. The majority of the participants were living in a controlled environment (family/dormitory), parents were living together and the students did not have a loss of academic year during school life.

\section{Alcohol use}

Characteristics of alcohol consumption, prevalence rates of lifetime use of alcohol, also risky and heavy drinking of the participants according to sex are all demonstrated in Table 2. Lifetime use of alcohol, risky drinking and heavy drinking were signifi-

Table 2. Characteristics of alcohol consumption; prevalence of lifetime use of alcohol, risky and heavy drinking

\begin{tabular}{|c|c|c|c|}
\hline & $\begin{array}{l}\text { Females } \\
(n=1629)\end{array}$ & $\begin{array}{c}\text { Males } \\
(n=1344)\end{array}$ & $\begin{array}{c}\text { Total } \\
(\mathbf{n}=2973)\end{array}$ \\
\hline \multicolumn{4}{|l|}{$\begin{array}{l}\text { Frequency of alcohol consump- } \\
\text { tion } n(\%)\end{array}$} \\
\hline None & $427(26.2)$ & $281(20.9)$ & $708(23.8)$ \\
\hline Once & $259(15.9)$ & $150(11.2)$ & $409(13.8)$ \\
\hline 1-3 times a month & $784(48.1)$ & $590(43.9)$ & $1374(46.2)$ \\
\hline 1-3 times a week & $138(8.5)$ & $272(20.2)$ & $410(13.8)$ \\
\hline Almost everyday & $21(1.3)$ & $51(3.8)$ & $72(2.4)$ \\
\hline \multicolumn{4}{|l|}{$\begin{array}{l}\text { Quantity of SD consumed daily } \\
\text { n (\%) }\end{array}$} \\
\hline $1-2 \mathrm{SD}$ & $638(53.1)$ & $365(34.3)$ & $1003(44.3)$ \\
\hline 3-4 SD & $304(25.3)$ & 307 (28.9) & $611(27)$ \\
\hline $5-6 \mathrm{SD}$ & $78(6.5)$ & $207(19.5)$ & $285(12.6)$ \\
\hline$\geq 7 \mathrm{SD}$ & $22(1.8)$ & $90(8.5)$ & $112(4.9)$ \\
\hline \multicolumn{4}{|l|}{$\begin{array}{l}\text { Frequency of consuming } \geq 6 \text { SD } \\
\text { at one occasion } n(\%)\end{array}$} \\
\hline$<1$ a month & $293(24.4)$ & $321(30.2)$ & $614(27.1)$ \\
\hline Once a month & $119(9.9)$ & $210(19.8)$ & $329(14.5)$ \\
\hline Once a week & $33(2.7)$ & $107(10.1)$ & $140(6.2)$ \\
\hline Almost everyday & $4(0.3)$ & $20(1.9)$ & $24(1.1)$ \\
\hline \multirow[t]{2}{*}{ Lifetime use of alcohol $n(\%)$} & $1202(73.8)$ & $1063(79.1)$ & $2265(76.2)$ \\
\hline & $\chi^{2}=11.422$ & $\mathrm{p}<0.001$ & \\
\hline \multirow[t]{2}{*}{ Risky drinking n (\%) } & $153(9.4)$ & $208(15.5)$ & $361(12.1)$ \\
\hline & $\chi^{2}=136.021$ & $\mathrm{p}<0.001$ & \\
\hline Heavy drinking $\mathbf{n}(\%)$ & $459(28.1)$ & $658(48.9)$ & $1107(37.2)$ \\
\hline
\end{tabular}

SD: standard drink 
cantly higher in males than females.

Factors associated with lifetime use of alcohol, risky drinking and heavy drinking

Variables affecting lifetime use of alcohol, risky and heavy drinking are demonstrated in Table 3. Living alone or with friends, history of substance use, smoking and problematic alcohol use of siblings were the factors affecting lifetime use of alcohol; male gender, history of substance use, smoking and problematic alcohol use of siblings were the factors affecting risky drinking and male gender, living alone or with friends, history of substance use and smoking were the factors affecting heavy drinking.

Among students with the anamnesis of lifetime use of alcohol, risky and heavy drinking, also significantly higher prevalence of consumption of energy drink, engaging in physical fights and getting injured, carrying knives/penknives/arms, being exposed to violence from partner, self-harming behavior and suicide planning/attempts were observed. . However, experience of unsafe sexual activity was higher only among heavy- drinking students (Table 4).

Students with an anamnesis of heavy drinking and risky drinking evaluated their physical health more negatively than those who were not $\left(\chi^{2}=6.954\right.$, $\mathrm{p}=0.031 ; \chi^{2}=15.415, \mathrm{p}<0.001$, respectively). This difference was not observed in students with an anamnesis of lifetime use of alcohol. Psychological health was evaluated more negatively by the students with an anamnesis of lifetime use of alcohol and heavy drinking than the students without $\left(\chi^{2}=16.361\right.$, $\mathrm{p}<0.001 ; \quad \chi^{2}=6.272, \quad \mathrm{p}=0.043, \quad$ respectively). Additionally, depression and anxiety scores were significantly higher in students with an anamnesis of lifetime use of alcohol and risky drinking (for lifetime use of alcohol and depression $\mathrm{t}=-2.815, \mathrm{p}=0.005$; for lifetime use of alcohol and anxiety $\mathrm{t}=-2.196$,

Table 3. Variables affecting lifetime use of alcohol, risky and heavy drinking.

\begin{tabular}{|c|c|c|c|c|c|c|}
\hline & \multirow[b]{2}{*}{$\mathbf{p}$} & \multirow[b]{2}{*}{ B } & \multirow[b]{2}{*}{ Std. Error } & \multirow[b]{2}{*}{$\beta$} & \multicolumn{2}{|c|}{$\% 95$ CI } \\
\hline & & & & & Lower & Upper \\
\hline \multicolumn{7}{|l|}{ Lifetime use of alcohol } \\
\hline Male gender & 0.899 & -0.002 & 0.015 & -0.002 & -0.031 & 0.028 \\
\hline Poor economic status & 0.607 & 0.012 & 0.023 & 0.009 & -0.033 & 0.057 \\
\hline Living alone/with friends & 0.001 & 0.054 & 0.016 & 0.061 & 0.016 & 0.077 \\
\hline History of substance use & 0.000 & 0.111 & 0.017 & 0.116 & 0.077 & 0.145 \\
\hline History of smoking & 0.000 & 0.234 & 0.016 & 0.274 & 0.204 & 0.265 \\
\hline Problematic alcohol use of parents & 0.262 & 0.024 & 0.021 & 0.022 & -0.018 & 0.066 \\
\hline Problematic alcohol use of siblings & 0.000 & -0.110 & 0.023 & -0.091 & -0.155 & -0.064 \\
\hline Constant & 0.000 & 0.597 & 0.013 & & 0.475 & 0.605 \\
\hline Risky drinking & 0.001 & 0.051 & 0.015 & 0.069 & 0.020 & 0.081 \\
\hline Male gender & 0.804 & 0.006 & 0.023 & 0.005 & -0.040 & 0.051 \\
\hline Poor economic status & 0.126 & 0.025 & 0.016 & 0.032 & -0.007 & 0.056 \\
\hline Living alone/with friends & 0.000 & 0.074 & 0.017 & 0.094 & 0.040 & 0.107 \\
\hline History of substance use & 0.023 & 0.038 & 0.017 & 0.049 & 0.005 & 0.070 \\
\hline History of smoking & 0.055 & 0.041 & 0.022 & 0.043 & -0.001 & 0.084 \\
\hline Problematic alcohol use of parents & 0.000 & 0.111 & 0.024 & 0.102 & 0.063 & 0.159 \\
\hline Problematic alcohol use of siblings & 0.000 & 0.056 & 0.015 & & 0.027 & 0.086 \\
\hline \multicolumn{7}{|l|}{ Constant } \\
\hline Heavy drinking & 0.000 & 0.187 & 0.020 & 0.187 & 0.148 & 0.226 \\
\hline Male gender & 0.398 & -0.025 & 0.030 & -0.016 & -0.084 & 0.033 \\
\hline Poor economic status & 0.000 & 0.102 & 0.020 & 0.098 & 0.061 & 0.142 \\
\hline Living alone/with friends & 0.000 & 0.166 & 0.022 & 0.155 & 0.123 & 0.208 \\
\hline History of substance use & 0.000 & 0.204 & 0.021 & 0.197 & 0.162 & 0.246 \\
\hline History of smoking & 0.946 & 0.002 & 0.028 & 0.001 & -0.052 & 0.056 \\
\hline Problematic alcohol use of parents & 0.933 & -0.003 & 0.031 & -0.002 & -0.064 & 0.059 \\
\hline Problematic alcohol use of siblings & 0.000 & 0.183 & 0.019 & & 0.145 & 0.220 \\
\hline Constant & & & & & & \\
\hline
\end{tabular}

CI: Confidence Interval CI: Confidence Interval 
$\mathrm{p}=0.028$; for risky drinking and depression $\mathrm{t}=-4.550$, $\mathrm{p}<0.001$; for risky drinking and anxiety $\mathrm{t}=-5.119$, $\mathrm{p}<0.001)$.

\section{DISCUSSION}

Variations in the definitions and measurements used to investigate alcohol use make it difficult to compare our data with the other studies carried out on this issue. Therefore, our results will be compared with studies using similar methods as much as possible.

The findings of the present study point out that lifetime use of alcohol (76\%) and heavy drinking (37\%) are common among university students in Izmir. Twelve percent of the survey participants had risky drinking. In a study ${ }^{(14)}$ performed in five different provinces (Istanbul, Ankara, Izmir, Mersin, Mugla) of Turkey with 2000 university students, it was established that the prevalence of lifetime use of alcohol was $77 \%$, and risky drinking was $14 \%$ in Izmir $(n=253)$. These results indicate that within the last four years, there was no marked increase in the prevalence of lifetime use of alcohol and risky drink- ing among university students in Izmir. However, these high rates of lifetime use of alcohol and heavy drinking among university students may be associated with starting a life out of family control and meeting with a different culture in which drinking is a way of socialization with peers.

In the present study, it was established that incidence rates of lifetime use of alcohol and risky and heavy drinking are much higher in males than females. These findings are consistent with the studies performed with university students in Turkey ${ }^{(12,14,18)}$, Europe ${ }^{(11)}$ and Asia ${ }^{(19)}$. Epidemiological studies carried out at certain intervals in the USA, it was demonstrated that the incidence of heavy drinking has recently increased among women ${ }^{(4)}$. Additionally, two studies from UK reported comparable prevalence rates of heavy drinking among male and female students ${ }^{(11)}$. In our sample, the rate of heavy drinking in women was found to be as high as $28 \%$ which is striking. With economic development and changes in gender roles, alcohol use among women has increased. This is an important issue in that it increases the probability of being exposed to sexual abuse and

Table 4. Factors associated with lifetime use of alcohol, risky and heavy drinking.

\begin{tabular}{|c|c|c|c|}
\hline & Lifetime use of alcohol & Risky drinking & Heavy drinking \\
\hline & $\begin{array}{c}\text { Present } \\
\text { n }(\%)\end{array}$ & $\begin{array}{c}\text { Present } \\
\text { n }(\%)\end{array}$ & $\begin{array}{c}\text { Present } \\
\text { n (\%) }\end{array}$ \\
\hline \multirow[t]{2}{*}{ Engaging in physical fights } & $77(10.9) \quad 423(18.7)$ & $327(17.2) \quad 96(26.6)$ & $159(13.7) \quad 264(23.8)$ \\
\hline & $\chi^{2}=23.457, p<0.001$ & $\chi^{2}=17.724, p<0.001$ & $\chi^{2}=38.147, p<0.001$ \\
\hline \multirow[t]{2}{*}{ Unsafe sexual activity } & $15(2.1) \quad 70(3.1)$ & $54(2.8) \quad 16(4.4)$ & $26(2.2)$ \\
\hline & $\chi^{2}=1.834, p=0.176$ & $\chi^{2}=2.581, p=0.108$ & $\chi^{2}=5.652, p=0.017$ \\
\hline \multirow[t]{2}{*}{ Consumption of energy drink } & $333(47) \quad 1761(77.7)$ & $1465(76.9) \quad 296(82)$ & $822(71) \quad 939(84.8)$ \\
\hline & $\chi^{2}=244.352, p<0.001$ & $\chi^{2}=4.475, p=0.034$ & $\chi^{2}=62.657, p<0.001$ \\
\hline \multirow[t]{2}{*}{ Self-harm behavior } & $67(9.5) \quad 391(17.3)$ & $295(15.5) \quad 96(26.6)$ & $171(14.8) \quad 220(19.9)$ \\
\hline & $\chi^{2}=25.178, p<0.001$ & $\chi^{2}=26.174, p<0.001$ & $\chi^{2}=10.334, p<0.001$ \\
\hline \multirow[t]{2}{*}{ Getting injured in physical fights } & $22(3.1) \quad 132(5.8)$ & $38(10.5)$ & $88(7.9)$ \\
\hline & $\chi^{2}=8.128, p=0.004$ & $\chi^{2}=17.274, p<0.001$ & $\chi^{2}=17.758, p<0.001$ \\
\hline \multirow[t]{2}{*}{ Carrying knives/penknives/arms } & $73(10.3) \quad 335(14.8)$ & $261(13.7) \quad 74(20.5)$ & $120(10.4) \quad 215(19.4)$ \\
\hline & $\chi^{2}=9.142, p=0.002$ & $\chi^{2}=11.104, p<0.001$ & $\chi^{2}=36.855, p<0.001$ \\
\hline \multirow[t]{2}{*}{ Exposure to violence from a partner } & $34(4.8) \quad 191(8.4)$ & $148(7.8) \quad 43(11.9)$ & $110(9.9)$ \\
\hline & $\chi^{2}=10.163, p<0.001$ & $\chi^{2}=6.730, p=0.009$ & $\chi^{2}=6.344, p=0.012$ \\
\hline \multirow{2}{*}{ Suicidal plans/attempts } & $119(16.8) \quad 618(27.3)$ & $498(26.2) \quad 120(33.2)$ & $292(25.2) \quad 326(29.4)$ \\
\hline & $\chi^{2}=31.756, p<0.001$ & $\chi^{2}=6.730, p=0.009$ & $\chi^{2}=5.112, p=0.024$ \\
\hline
\end{tabular}


consequently it leads to serious health and social problems in women ${ }^{(4,9)}$. In terms of potential health consequences female students should be particularly informed about drinking limits.

In this study, living alone or with friends, history of substance use, smoking and problematic alcohol use of siblings were found to be factors affecting lifetime use of alcohol; male gender, history of substance use, smoking and problematic alcohol use of siblings were found to be factors affecting risky drinking and male gender, living alone or with friends, history of substance use and smoking were found to be factors affecting heavy drinking. In similar studies carried out in various regions of the world, in countries with different university students, it has been established that there are different factors affecting alcohol use and risky and heavy drinking ${ }^{(5,7,18,20,21)}$. The fact that living alone/with friends is a factor affecting lifetime use of alcohol and heavy drinking suggests that living in controlled environments such as family or dormitory may be a protective factor against drinking problems. In a study performed in Australia, it was shown that students whose alcohol use was under control experienced alcohol related problems at a seven fold lower rate than uncontrolled students ${ }^{(22)}$. In another study in the US, it was reported that students whose parents do not allow them to use alcohol at school, consumed lower amounts of alcohol and experienced lower rates of problems associated with alcohol than students who were allowed to do so ${ }^{(23)}$. All but two studies carried out so far ${ }^{(24,25)}$, have found a relationship between smoking and the prevalence of alcohol consumption and heavy drinking ${ }^{(19)}$. Likewise, in this group, as alcohol consumption increased, so does the use of illicit drugs ${ }^{(11,26)}$. Additionally, this study reveals that problematic alcohol use of siblings is associated with students' lifetime use of alcohol and risky drinking. The influence of siblings' alcohol use is mentioned in many publications ${ }^{(27)}$. Furthermore, the magnitude of siblings' influence on adolescents' alcohol use is often greater than parental influences. Additionally, behavioral geneticists have reported that similarities in alcohol use of siblings' are significant above and beyond the contributions of shared genetics and shared parenting. The researchers stated that similarities are mediated via social and cognitive pathways ${ }^{(28)}$. The determination of the factors affecting alcohol use and risky drinking among university students and formulating preventive interventions accordingly is important for decreasing the risk of the development of alcohol dependence. The results of the present study show that preventive interventions should be especially focused on students living alone/ with friends, students with a history of substance use and smoking and those having siblings with a history of problematic alcohol use.

In the present study, the incidence rates of being involved in physical fights and getting injured, carrying knives/penknives/arms, being exposed to violence from partners, self-inflicting behaviors and suicidal ideation and attempts were found to be significantly higher in the students with lifetime use of alcohol and risky and heavy drinking. Students with lifetime use of alcohol and heavy drinking evaluated their psychological health more negatively and also depression and anxiety scores were higher in students with lifetime use of alcohol and risky drinking. In addition, self-perceived physical health was worse in students with heavy drinking and risky drinking. Furthermore, the frequency of unsafe sexual activity was high in heavy drinkers. Comparing data regarding alcohol- associated problems between studies is difficult since different methods of measurement are being used both in the evaluation of these data and characteristics of alcohol use. Irrespective of methodological differences, it was reported in two universities in Lebanon that physical fight was associated with alcohol use ${ }^{(19)}$, and that the rate of unsafe sexual activity was high in the first year students of Brazil ${ }^{(29)}$. In a study carried out in Switzerland, it was established that self-perceived psychological health is not associated with the frequency of alcohol use and heavy drinking ${ }^{(30)}$. Additionally, it was reported that neither depression nor anxiety were associated with frequency of drinking, average alcohol consumption 
or heavy drinking in Finland and UK ${ }^{(11)}$. However, in a recent study, especially female students who drank more frequently were six times more likely to have experienced mental health conditionss ${ }^{(6)}$. Likewise, in the Cross National Students' Health Study, it was reported that students who experienced never or seldom depressive moods had lower prevalence of risky drinking ${ }^{(11)}$. Concerning the relationship of physical health and alcohol use, conflicting results have been obtained in studies carried out in different universities of Europe and Asia ${ }^{(11)}$. No correlation between volume of drinking and general health was found in Swedish students ${ }^{(30)}$. On the other hand, a multicenter study from Germany, Lithuania and Spain found both positive (backache/neckache) as well as negative (gastrointestinal complaints) associations between frequent alcohol consumption and several aspects of physical health ${ }^{(31)}$. Recent literature data indicate that especially heavy drinking increases alcohol- associated problems ${ }^{(6,10)}$. In addition, as the duration of heavy drinking is prolonged, the probability of the occurrence of these problems increases (4). In the present study, we showed that lifetime use of alcohol and risky drinking was also associated with alcohol related problems. This data shows that not only heavy-drinking students but also risky drinkers and students with lifetime use of alcohol should be the targets of prevention initiatives. Universities should carry out their own surveys on drinking behavior of their students to determine the alcohol-related harm among them. Furthermore, other reasons such as drinking motives, coping styles, drinking location and drinking context that are associated with alcohol-related harm should be evaluated in future studies.

It is important to prepare prevention programs for university students taking into consideration the predictive factors and alcohol associated problems mentioned above. Indeed, individual screening and counseling interventions, alcohol control policies and their implementations and large scale initiatives with community and university cooperation, all decrease alcohol use and alcohol associated social, physical and psychological problems in university students (32). The development of such effective interventions among university students in Turkey has been disregarded and should be given priority.

One of the limitations of the present study is its cross-sectional design. It is possible to examine the association between drinking and related factors, but it is not possible to make causal inferences. It is obvious that longitudinal studies and repeated measurements will better clarify the relationship between them. Additionally, the analyses based on self-reported data may lead to underestimation because of underreporting, however previous studies have demonstrated that self-reports of alcohol use are considered to be reliable and valid ${ }^{(33)}$. Another limitation of the study seems to be the fact that it is web-based, but comparative studies performed with university students have indicated that collecting data with webbased method for the assessment of health risk behaviors does not discourage participants and rate of response is comparable to that of other data collection methods ${ }^{(34,35)}$. Additionally, our sample was only representative for one university in Izmir, which limits the generalization of our results to Turkey.

\section{CONCLUSION}

The results of the present study indicate that prevalence of life time use of alcohol, risky and heavy drinking is high among students in Izmir, which is the third biggest metropolitan city in Turkey. Negative consequences of alcohol make it imperative to develop primary prevention programs targeting this group. In this context, according to laws which have been put into effect in Turkey since 2013 June, it is illegal to sell alcohol to anyone under the age of 18 and between the hours of 10 p.m. - 6 a.m., and to open liquor stores in close proximity of educational institutions and student dormitories. Further studies are required to evaluate the effect of these legal regulations on the future practice of alcohol consumption. 


\section{Acknowledgements}

This study was part of a Project called as Youth Observation Study (GENCIZ) in Turkey, which through its web site allows surveys for high school and university students from different cities.

This study was presented as poster presentation at the Annual Meeting of International Society of Addiction Medicine (ISAM) (November 21-23, 2013).

\section{REFERENCES}

1. Ilhan IO, Yildirim F, Demirbas H, Dogan YB. Prevalence and sociodemographic correlates of substance use in a universitystudent sample in Turkey. Int J Public Health. 2009; 54(1):40-4. http://dx.doi.org/10.1007/s00038-009-7049-1

2. Lorant V, Nicaise P, Soto VE, d'Hoore W. Alcohol drinking among college students: college responsibility for personal troubles. BMC Public Health. 2013;13:615. http://dx.doi.org/10.1186/1471-2458-13-615

3. Substance Abuse and Mental Health Services Administration. Results from the 2011 National Survey on Drug Use and Health: summary of national findings, NSDUH Series H-44, HHS Publication No. (SMA) 12-4713. Rockville, MD: Substance Abuse and Mental Health Services Administration. 2012.

4. Boyd CJ, McCabe SE, Morales M. College students' alcohol use: a critical review. Annual Review of Nursing Research. 2005;23:179-211. http://search.proquest.com/docview/197288962/fulltextPDF/ 31372B97D17D4553PQ/1? accountid=10699

5. Akmatov MK, Mikolajczyk RT, Meier S, Krämer A. Alcohol consumption among university students in North RhineWestphalia, Germany-Results from a multicenter cross-sectional study. J Am Coll Health. 2011;59(7):620-6. http://dx.doi.org/10.1080/07448481.2010.520176

6. Diep PB, Knibbe RA, Giang KB, De Vries N. Alcoholrelated harm among university students in Hanoi, Vietnam. Glob Health Action. 2013;6:1-10. http://dx.doi.org/10.3402/gha.v6i0.18857

7. Kypri K, Paschall MJ, Langley J, Baxter J, Cashell-Smith M, Bourdeau B. Drinking and alcohol-related harm among New Zealand university students: findings from a national Webbased survey. Alcohol Clin Exp Res. 2009;33(2):307-14. http://dx.doi.org/10.1111/j.1530-0277.2008.00834.x

8. WHO. Alcohol. Fact sheet. Available from: http://www.who. int/substance_abuse/publications/global_alcohol_report/ msb_gsr_2014_1.pdf?ua=1 [cited 13 February 2012].

9. WHO. Global status report on alcohol and health. Available from: http://www.who.int/substance_abuse/publications/ global_alcohol_report/msb_gsr_2014_1.pdf?ua=1 [cited 03 March 2014].

10. Antai D, Lopez GB, Antai J, Anthony DS. Alcohol drinking patterns and differences in alcohol-related harm: a population-based study of the United States. Biomed Res Int. 2014;2014:853410.

http://dx.doi.org/10.1155/2014/853410
11. Wicki M, Kuntsche E, Gmel G. Drinking at European universities? A review of students' alcohol use. Addict Behav. 2010;35(11):913-24. http://dx.doi.org/10.1016/j.addbeh.2010.06.015

12. Akvardar Y, Demiral Y, Ergör G, Ergör A, Bilici M, Akil Ozer O. Substance use in a sample of Turkish medical students. Drug Alcohol Depend. 2003;72(2):117-21. http://dx.doi.org/10.1016/S0376-8716(03)00192-3

13. Erhan Deveci S, Açik Y, Ferdane Oguzöncül A, Deveci F. Prevalence and factors affecting the use of tobacco, alcohol and addictive substance among university students in eastern Turkey. Southeast Asian J Trop Med Public Health. 2010;41(4):996-1007. http://www.tm.mahidol.ac.th/seameo/2010-41-4/27-4784.pdf

14. Ilhan IO, Yildirim F, Demirbaş H, Doğan YB. Alcohol use prevalence and sociodemographic correlates of alcohol use in a university student sample in Turkey. Soc Psychiatry Psychiatr Epidemiol. 2008;43(7):575-83.

http://dx.doi.org/10.1007/s00127-008-0335-z

15. Ewing JA. Detecting alcoholism. The CAGE questionnaire. JAMA. 1984;252(14):1905-7. http://dx.doi.org/10.1001/jama.1984.03350140051025

16. King M. At risk drinking among general practice attenders: validation of the CAGE questionnaire. Psychol Med. 1986;16:213-7. http://dx.doi.org/10.1017/S0033291700002658

17. Ogel K, Basabak A, Koc C, Aksoy A, Karadayi G. Psychometric properties of different forms of the addiction profile index (BAPI). Bulletin of Clinical Psychopharmacology. 2011;21(Suppl. 2):151.

18. Oksuz E, Malhan S. Socioeconomic factors and health risk behaviors among university students in Turkey: questionnaire study. Croat Med J. 2005;46(1):66-73. http://neuron.mefst.hr/docs/CMJ/issues/2005/46/1/15726678.pdf

19. Karam EG, Maalouf WE, Ghandour LA. Alcohol use among university students in Lebanon: prevalence, trends and covariates. The IDRAC University Substance Use Monitoring Study(1991 and 1999).DrugAlcoholDepend.2004;76(3):27386. http://dx.doi.org/10.1016/j.drugalcdep.2004.06.003

20. Heather N, Partington S, Partington E, Longstaff F, Allsop S, Jankowski $\mathrm{M}$, et al. Alcohol use disorders and hazardous drinking among undergraduates at English universities. Alcohol Alcohol. 2011;46:270-7. http://dx.doi.org/10.1093/alcalc/agr024

21. Talbott LL, Martin RJ, Usdan SL, Leeper JD, Umstattd MR, Cremeens JL, et al. Drinking likelihood, alcohol problems, and peer influence among first-year college students. Am J Drug Alcohol Abuse. 2008;34:433-40. http://dx.doi.org/10.1080/00952990802122655

22. McBride N, Farringdon F, Midford R. What harms do young Australians experience in alcohol use situations? Aust N Z J Public Health. 2000;24:549. http://dx.doi.org/10.1111/j.1467-842X.2000.tb00723.x

23. Caitlin A, Beau A, Rob T. The impact of parental modeling and permissibility on alcohol use and experienced negative drinking consequences in college. Addict Behav. 2009;34:542-7. http://dx.doi.org/10.1016/j.addbeh.2009.03.019

24. Underwood B, Fox K. A survey of alcohol and drug use among UK based dental undergraduates. British Dental Journal. 2000;189:314-7. http://dx.doi.org/10.1038/sj.bdj.4800756

25. Stock C, Mikolajczyk R, Bloomfield K, Maxwell AE, 
Ozcebe H, Petkeviciene J, et al. Alcohol consumption and attitudes towards banning alcohol sales on campus among European university students. Public Health. 2009;123:122-9.

http://dx.doi.org/10.1016/j.puhe.2008.12.009

26. Saingam D, Assanangkornchai S, Geater AF. Drinkingsmoking status and health risk behaviors among high school students in Thailand. J Drug Educ. 2012;42:177-93. http://dx.doi.org/10.2190/DE.42.2.d

27. Whiteman SD, Jensen AC, Maggs JL. Similarities in adolescent siblings' substance use: testing competing pathways of influence. J Stud Alcohol Drugs. 2013;74(1):104-13. https://doi.org/10.15288/jsad.2013.74.104

28. Whiteman SD, Jensen AC, Mustillo SA, Maggs JL. Understanding sibling influence on adolescents' alcohol use: Social and cognitive pathways. Addict Behav. 2016;53:1-6. http://dx.doi.org/10.1016/j.addbeh.2015.09.007

29. Pillon SC, O'Brien B, Piedra Chavez KA. The relationship between drugs use and risk behaviors in Brazilian university students. Rev Lat Am Enfermagem. 2005;13:1169-76. http://dx.doi.org/10.1590/S0104-11692005000800011

30. Vaez M, Laflamme L. Health behaviors, self-rated health, and quality of life: a study among first-year Swedish university students. J Am Coll Health. 2003;51:156-62.

http://dx.doi.org/10.1080/07448480309596344
31. Stock C, Kücük N, Miseviciene I, Guillén-Grima F, Petkeviciene J, Aguinaga-Ontoso I, et al. Differences in health complaints among university students from three European countries. Prev Med. 2003;37(6 Pt 1):535-43. https://doi.org/10.1016/j.ypmed.2003.07.001

32. Hingson RW, Zha W, Weitzman ER. Magnitude of and trends in alcohol-related mortality and morbidity among U.S. college students ages 18-24, 1998-2005. J Stud Alcohol Drugs. 2009;:Suppl 16:12-20. http://dx.doi.org/10.1146/annurev.publhealth.26.021304.144652

33. Midanik L. Validity of self-report alcohol use: A literature review and assessment. Br J Addict. 1988;83:1019-30. http://dx.doi.org/10.1111/j.1360-0443.1988.tb00526.x

34. Pealer L, Weiler RM. Guidelines for designing a Webdelivered college health risk behavior survey: lessons learned from the University of Florida Health Behavior Survey. Health Promot Pract. 2003;4:171-9. http://dx.doi.org/10.1177/1524839902250772

35. Pealer LN, Weiler RM, Pigg RM Jr, Miller D, Dorman SM. The feasibility of a web-based surveillance system to collect health risk behavior data from college students. Health Educ Behav. 2001;28:547-59. http://dx.doi.org/10.1177/109019810102800503 